\title{
ANALISIS DEFINISI SAHABAT DALAM BEBERAPA KARYA SYIAH MELAYU
}

\author{
AN ANALYSIS OF THE DEFINITION OF COMPANION IN \\ SEVERAL MALAY SHIITE WORKS
}

\section{Mohd Aizam Mas'od \& Mohd Fauzi Hamat}

Department of `Aqidah \& Islamic Thought. Academy of Islamic Studies. University of Malaya. 50603. Kuala Lumpur. Malaysia.

Email: *abuhaseef@live.com

DOI: https://doi.org/10.22452/afkar.vol20no1.1

\section{Khulasah}

Fahaman Syiah telah tersebar di Malaysia menjelang tahun 1980-an selepas berlaku Revolusi Iran pada tahun 1979. Dalam konteks Malaysia, proses penyebaran Syiah kepada masyarakat Melayu berlaku menerusi pelbagai cara. Antara medium penyebaran yang memberikan impak ketara adalah penyebaran karya-karya Syiah berbahasa Melayu. Pelbagai isu dibangkitkan dalam karya-karya tersebut seperti persoalan Imāmah, Imam al-Mahdi, nikah mut'ah dan keadilan sahabat. Walau bagaimanapun, makalah ini akan memberi tumpuan terhadap definisi sahabat dalam karya-karya tersebut. Dengan menggunakan pendekatan kualitatif, kajian ini berteraskan dua kaedah pengkajian iaitu kaedah pengumpulan data dan penganalisisan data. Menerusi metode dokumentasi dalam kaedah pengumpulan data, kajian ini merujuk kepada dua buah karya Syiah Melayu terpilih iaitu Meniti Titian Kebenaran karangan Khair Izzah dan Perempuan Nan Bercinta karya Faisal Tehrani. Manakala metode komperatif digunakan dalam menganalisis data dengan membuat perbandingan antara definisi sahabat menurut Syiah dan Ahl alSunnah wa al-Jama'ah. Kajian merumuskan, konsep sahabat dari perspektif karya Syiah Melayu adalah bersamaan dengan doktrin asal Shi'ah Imāmiyyah 
Ithnā 'Ashariyyah. Ia bermula dengan pemahaman istilah sahabat yang tidak membawa apa-apa makna yang signifikan dari sudut syarak kecuali sekadar melambangkan seseorang yang telah bergaul dengan Nabi SAW semasa hayatnya. Kepercayaan ini bertentangan dengan pegangan Ahl al-Sunnah wa alJama'ah. Ini kerana, istilah sahabat memiliki sandaran yang kukuh berdasarkan nas-nas syarak.

Kata kunci: sahabat; karya Syiah Melayu; Shī'ah Imāmiyyah Ithnā 'Ashariyyah; Ahl al-Sunnah wa alJama'ah, Malaysia.

\begin{abstract}
The belief of Shiite has been spread in Malaysia by the 1980s after the Iranian revolution in 1979. In the Malaysian context, dissemination of Shiite to the Malay community occurred through a variety of ways. Among the spreading mediums that had a tangible impact were the spread of Malay Shiite works. Various issues arose in the works such as the issues of Imamah, Imam al-Mahdi, mut 'ah marriage and the justice of the companions. However, this article will focus on the definition of the companions in the works. Using a qualitative approach, this study is based on two methods of assessment, namely data collection and data analysis. Through the method of documentation in the method of data collection, this study refers to two selected Shiite Malay works entitled Meniti Titian Kebenaran by Khair Izzah and Perempuan Nan Bercinta by Faisal Tehrani. Whereas comparative method is used in analyzing data by comparing the definition of companions according to Shiite and Ahl al-Sunnah wa al-Jama'ah (Sunnite). The study concludes that the concept of companions from the perspective of Malay Shiite works is equivalent to the original doctrine of Shīah Imāmiyyah Ithnā 'Ashariyyah. It begins with the understanding of the term of companion that was maintained according to the meaning of the language. The term companion does not bring any significant meaning from the point
\end{abstract}


of shara except merely symbolising someone who socialised with Prophet PBUH during his lifetime. This belief is contrary to Ahl al-Sunnah wa alJama'ah. This is because the term companion has a strong foundation based on texts of Shari'ah. Understanding the term of companion with the meaning of the language solely regardless of the proponents submitted by the Shari'ah with the correct understanding can cause the failure to understand the concept of companion as a whole.

Keywords: companion; Shiite Malay works; Shīà Imāmiyyah Ithnā 'Ashariyyah; Ahl al-Sunnah wa alJama'ah; Malaysia.

\section{Pendahuluan}

Para sahabat merupakan golongan yang paling hampir dengan Rasūlullah SAW. Ahl al-Sunnah wa al-Jamā'ah bersepakat bahawa seluruh sahabat bersifat adil ('udūl). Menurut Ibn Hajar, tiada yang berselisih pendapat tentang hal ini kecuali segelintir orang yang digelar sebagai ahli bid'ah. Maka wajib bagi setiap muslim untuk meyakini sifat sahabat tersebut kerana telah ditetapkan bahawa seluruh sahabat adalah ahli syurga, tiada seorang pun dalam kalangan mereka yang akan masuk ke neraka ${ }^{1}$. Iktikad ini dipegang oleh majoriti umat Islam di seluruh dunia yang berpegang dengan akidah Ahl al-Sunnah wa al-Jamā'ah termasuk di Malaysia. Namun begitu, dengan penyebaran fahaman Syiah, terdapat usaha-usaha yang cuba mempertikaikan kedudukan para sahabat menerusi bahanbahan penulisan dalam Bahasa Melayu.

Justeru itu, kajian ini akan menganalisis definisi sahabat sebagaimana yang terkandung dalam beberapa karya tersebut. Ia bagi mengetahui kerangka teori pemikiran Syiah terhadap konsep sahabat secara konkrit. Dua buah karya Syiah berbahasa Melayu yang diteliti iaitu

\footnotetext{
${ }^{1}$ Ahmmad bin 'Alī bin Hajar al-'Asqalanī, al-Ișabah fī Tamyiz al-Ṣaḥabah (Beirut: Dar al-Jìl, 1992), 1: 10-12.
} 
Meniti Titian Kebenaran: Menyingkap Kebenaran Mazhab Rasul dan Ahlul Bait ${ }^{2}$ karangan Khair Izzah dan Perempuan Nan Bercinta ${ }^{3}$ karangan Faisal Tehrani. Keduadua karya berkenaan telah dikenakan perintah larangan oleh Kementerian Dalam Negeri, masing-masing pada 9 Januari 2014, No. Warta P.U. (A) 13 dan 22 April 2014, No. Warta P.U. (A) 111. Antara sebab utama larangan adalah kerana mempromosikan fahaman Syiah yang bertentangan pegangan Ahl al-Sunnah wa al-Jamā'ah yang menjadi anutan rasmi di Malaysia. ${ }^{4}$

\section{Khair Izzah dan Karyanya Meniti Titian Kebenaran}

Khair Izzah merupakan nama samaran kepada Khaireen Syahreen bin A Malek. Memiliki perniagaan mengedar dan menjual buku-buku kajian, komputer, barangan aksesori dan penternakan itik dan kambing di bawah Syarikat Raudhah al-Hurr Resources Enterprise beralamat di Ulu Tiram, Johor. Dalam kata pengantar buku Meniti Titian Kebenaran, beliau mengaku sebagai penuntut di Kuliah Usuluddin dan Dakwah, Universiti al-Azhar, Mesir. Selain mengarang buku Meniti Titian Kebenaran, beliau juga ada mengarang buku lain yang turut mempertahankan ajaran Syiah Imamiyyah Ithna 'Ashariyyah dan mengkritik Ahl alSunnah wa al-Jama'ah iaitu Pertahan Syariat Muhammadiyah pada 2010. Selain itu, beliau pernah mewakili pihak Syiah Imamiyyah Ithna 'Ashariyyah dalam Dialog Sunni Syiah yang diadakan di Masjid Jamek Taman Perling, Johor Bahru pada 3 Februari 2013. ${ }^{5}$

${ }^{2}$ Khair Izzah, Meniti Titian Kebenaran (t.t.p. : Al-Muntazar Resources, 2011).

3 Faisal Tehrani, Perempuan Nan Bercinta (Kuala Lumpur: ITBM, 2012).

4 “Senarai Perintah Larangan”, Kementerian Dalam Negeri, dicapai 15 Mei 2015, http://epq.kdn.gov.my/epq/index.php?mod=public\&opt=pl. 15 Mei 2015.

${ }^{5}$ Seksyen Akidah, "Kertas Makluman Perkembangan Terkini Isu Syiah di Malaysia" (Bahagian Perancangan dan Penyelidikan, Jabatan Kemajuan Islam Malaysia, 2013), 10; "Debat Sunni Syiah Masjid 
Mengenai isi kandungan buku Meniti Titian Kebenaran, secara umumnya ia ditulis dengan jelas bertujuan untuk mempromosikan fahaman Syiah Imamiyyah Ithna 'Ashariyyah. Sekalipun tajuk besarnya agak kabur dan bersifat catchy, namun secara penuh disebutkan judulnya, Meniti Titian Kebenaran: Menyingkap Kebenaran Mazhab Rasul dan Ahlul Bait. Tajuk sedemikian sudah cukup menimbulkan tanda tanya di benak pembaca bahawa terdapat suatu mazhab baharu yang selama ini terselindung kebenarannya oleh sebab tertentu. Dalam kata pengantarnya, penulis menekankan kepentingan berfikir dan mengkaji dalam mencari kebenaran. Bukan sekadar bertaqlid kepada ibu bapa atau keturunan yang lebih banyak dipengaruhi oleh sentimen berbanding bersikap rasional dan profesional. ${ }^{6}$

Penulis merakamkan kekesalannya yang pernah menilai ajaran Syiah berdasarkan tulisan-tulisan daripada musuh-musuh Syiah. Namun dalam diam-diam beliau cuba mengkaji ajaran Syiah menerusi sumber-sumber Syiah sendiri. Akhirnya ia menjadi titik peralihan dalam pencarian beliau apabila mendapati hujah-hujah yang dikemukakan dalam sumber rujukan Syiah mampu menjawab semua pertikaian yang ditimbulkan oleh para ulama Ahl al-Sunnah wa al-Jamā'ah.

Justeru, buku ini ditulis dengan membawakan hujahhujah al-Qur'an, hadis, sejarah dan logik akal siapakah sebenarnya golongan Syiah Imamiyyah Ithna 'Ashariyyah itu. ${ }^{7}$ Umumnya, buku ini dikarang oleh penulis sebagai alat propaganda bagi menyebarkan fahaman Syiah Imamiyyah Ithna 'Ashariyyah. Argumentasi yang dibentangkan lebih bersifat konfrantatif terhadap fahaman Ahl al-Sunnah wa

Perling 2013: Analisis Ringkas", Meniti Titian Sebenar, dicapai 10 Januari 2016, http://titian-sebenar.blogspot.my/2014/02/debat-sunnisyiah-masjid-perling-2013.html..

${ }^{6}$ Khair Izzah, Meniti Titian Kebenaran, 1-51 (Kata Pengantar).

${ }^{7}$ Ibid. 
al- Jamā'ah dan defensif bagi mempertahankan kebenaran ajaran Syiah Imamiyyah Ithna 'Ashariyyah.

Justifikasi utama karya ini dipilih selain disebabkan larangan KDN, adalah kerana ia telah disebarkan dengan meluas secara percuma oleh pihak Syiah Melayu atas nama Majlis Syiah Malaysia ke masjid-masjid dan surau-surau ke seluruh negara. ${ }^{8}$ Ini menunjukkan bahawa ia adalah karya Syiah berbahasa Melayu yang paling diakui oleh golongan Syiah di Malaysia sebagai sumber yang boleh menjelaskan pegangan Syiah Melayu ketika ini. Turut dilampirkan bersama dalam penyebaran buku tersebut memorandum Majlis Syiah Malaysia bertarikh 6 Jun 2011 yang ditandatangani oleh peguamnya, Mohd Haidar bin Mohd Hashim kepada Yang Di Pertuan Agong dan Perdana Menteri Malaysia. Isi kandungannya adalah untuk merayu supaya warta pengharaman Syiah dan kesesatan Syiah dikaji semula dan dimansuhkan di peringkat negeri dan kebangsaan. ${ }^{9}$

\section{Faisal Tehrani dan Karyanya Perempuan Nan Bercinta}

Faisal Tehrani adalah nama pena bagi Mohd Faizal bin Musa. Beliau adalah seorang novelis berunsur Islam terkenal di Malaysia. Beliau juga merupakan ahli Human Rights Defender yang berdaftar dengan Front Line Defenders (FLD), iaitu sebuah badan dengan status khas Consultative Status with Economic and Social Council (ECOSOC) di Pertubuhan Bangsa-Bangsa Bersatu. Di samping itu, beliau adalah felo penyelidik di Al-Mustafa International Research Institute, Qom, Iran dan Penasihat kepada Islamic Republic of Iran Broadcasting (IRIB) Asia Tenggara. Pada 15 Disember 2013, beliau dilantik sebagai

\footnotetext{
${ }^{8}$ Seksyen Akidah, "Kertas Makluman Perkembangan Terkini Isu Syiah di Malaysia" (2013), 14.

${ }^{9}$ Seksyen Akidah, "Kertas Makluman Perkembangan Terkini Isu Syiah di Malaysia" (Bahagian Perancangan dan Penyelidikan, Jabatan Kemajuan Islam Malaysia, 2011), 22-23.
} 
Special Rapporteur oleh Shia Rights Watch yang berpusat di Washington DC, Amerika Syarikat.

Ketika ini beliau bertugas sebagai Felo Penyelidik di Institut Alam dan Tamadun Melayu (ATMA), Universiti Kebangsaan Malaysia. ${ }^{10}$ Beberapa buah buku beliau selain buku Perempuan Nan Bercinta telah dikenakan perintah larangan oleh KDN kerana dikenalpasti mengandungi unsur-unsur ajaran Syiah. Antaranya, Sebongkah Batu di Kuala Berang, Karbala dan Ingin Jadi Nasrullah yang dikenakan perintah larangan pada 1 April 2015 dengan Warta No. P.U. (A) 67. ${ }^{11}$

Novel Perempuan Nan Bercinta dikarang oleh Faisal Tehrani dengan bertemakan novel cinta yang amat digemari oleh golongan remaja, tetapi sarat dengan propaganda fahaman Syiah Imamiyyah Ithna 'Ashariyyah. Penulis menerapkan elemen perdebatan ilmiah untuk mempengaruhi pembaca bagi menonjolkan keabsahan ajaran Syiah Imamiyyah Ithna 'Ashariyyah dari segi epistemologi dan ideologi berbanding mazhab Ahl alSunnah wa al-Jamā'ah yang disifatkan sebagai tidak asli. ${ }^{12}$

Objektif tersebut tampak menyerlah menerusi kewujudan satu watak protagonis yang mewakili Syiah, tetapi mengaku seorang Sunni yang bertashayyu" Hasan (Dr. Ali Taqi), manakala lima lagi adalah watak antagonis yang mewakili wanita Islam feminis (Idora), penganut Aties (Briana), orientalis Kristian (Bastian), bekas penganut Salafi (Hashemi) dan penganut Sunni (Zanjabila). Menerusi watak Dr. Ali Taqi, penulis menerapkan apa yang menjadi ideologi pegangannya, sesuai dengan penegasannya pada kulit belakang karya tersebut, "Sejak

${ }^{10}$ Seksyen Akidah, "Laporan Mengenai Coalition Of Malaysia NGOs In The UPR Process (COMANGO)" (Bahagian Perancangan dan Penyelidikan, Jabatan Kemajuan Islam Malaysia, 2013), 11-12.

11"Senarai Perintah Larangan", Kementerian Dalam Negeri, http://epq.kdn.gov.my/e-pq/index.php?mod=public\&opt=pl. $15 \mathrm{Mei}$ 2015.

${ }^{12}$ Faisal Tehrani, Perempuan Nan Bercinta, 9. 


\section{5 dan Tuhan Manusia, Perempuan Nan Bercinta adalah karya Faisal Tehrani yang paling provokatif setakat ini."}

Secara umumnya, novel ini cuba memberikan gambaran bagaimana pegangan Ahl al-Sunnah wa alJamā'ah yang dianuti oleh majoriti umat Islam di dunia menjadi punca kepada pandangan negatif banyak pihak terhadap imej Islam itu sendiri. Penulis menggunakan instrumen perbualan, pembentangan seminar dan forum bagi mewujudkan perdebatan sama ada secara jelas atau tidak jelas, langsung atau tidak langsung bagi memperlihatkan keabsahan dan kerelevenan ajaran Syiah Imamiyyah Ithna 'Ashariyyah dalam menjawab segala persoalan umat bermula daripada isu gender, kekeluargaan, pemikiran pasca modernisme, perbandingan teologi, mazhab dan agama, isu hak asasi dan diskriminasi golongan minoriti, perjuangan Hezbollah dan sejarah awal kedatangan Islam ke Nusantara.

Kesemua topik ini dicerakinkan dengan menjadikan Ahl al-Sunnah wa al-Jamā'ah sebagai sasaran utama terhadap segala kepincangan dalam menangani isu umat. Walau bagaimanapun, penulis menutup novelnya secara anti-klimaks apabila menyatakan Sunni dan Syiah perlu saling melengkapi bagi mencapai matlamat generasi supramazhab, sedangkan idea-idea yang dibentangkan sebelumnya sarat dengan sikap prejudis dan provokatif terhadap Ahl al-Sunnah wa al-Jamā'ah.

Dapat disimpulkan, tema yang dipersembahkan dalam novel ini hanya terbahagi kepada tiga aspek. Pertama, mengangkat Syiah Imamiyyah Ithna 'Ashariyyah sebagai penyelesai kepada segala permasalahan dan mazhab yang relevan sepanjang zaman. Kedua, mempertikaikan Ahl alSunnah wa al-Jamā'ah sebagai pegangan asli yang diwariskan oleh Nabi SAW dan ketidakrelevanannya menangani pelbagai permasalahan ummah. Ketiga, 
perbandingan antara kedua-dua pegangan dalam menangani pelbagai isu dan persoalan.

Justeru, karya ini dipilih sebagai mewakili aliran Syiah Melayu kerana isi kandungannya yang jelas mempunyai anasir Syiah sehingga menimbulkan kegemparan dalam masyarakat Islam di Malaysia yang secara tradisinya berfahaman Ahl al-Sunnah wa al-Jamā'ah.

\section{Pemahaman Definisi Sahabat dalam Karya Syiah Melayu}

Persoalan sahabat antara isu yang banyak disentuh dalam kedua-dua karya Syiah tersebut. Gaya perbahasan dilihat amat provokatif kerana ia membentangkan hujah-hujah daripada Ahl al-Sunnah wa al-Jamā'ah sebelum dikritik. Khair Izzah terlebih dahulu membawakan definisi sahabat menurut Ahl al-Sunnah wa al-Jamā'ah sebagaimana dinukilkan daripada Ibn Hajar al-'Asqalani dan beberapa ulama Ahl al-Sunnah wa al-Jamā'ah yang lain. ${ }^{13}$ Selepas membentangkan beberapa definisi sahabat tersebut, beliau mengatakan:

"Inilah pengertian Sunni dalam memberikan penilaian bagi membuat rangkuman para sahabat Nabi. Mereka langsung tidak mengecualikan seorang pun dari kaum muslimin yang pernah hidup di zaman Rasul. Bahkan dengan melihat dan mendengar dari Nabi walaupun sekejap atau sekali seumur hidup sudah cukup sebagai syarat digelarkan sebagai sahabat Nabi. Bahkan mereka adalah golongan yang adil dan digelar mujtahid. Dengan ini timbullah sebuah hadits yang kononnya Nabi telah bersabda: Para sahabatku umpama bintang-bintang. Sesiapa sahaja yang

${ }^{13}$ Khair Izzah, Meniti Titian Kebenaran, 354. 


\section{kamu ikuti diantara mereka, pasti akan peroleh petunjuk hidayat." 14}

Beliau mengkritik definisi tersebut kerana mendakwa ia amat longgar sehingga merangkumkan semua orang yang pernah hidup pada zaman Rasulullah SAW tanpa seorang pun terkecuali. Sekalipun hanya sebentar melihat dan mendengar daripada Nabi atau bertemu Baginda sekali seumur hidup, ia sudah cukup sebagai syarat digelarkan sahabat Nabi. Apatah lagi apabila Ahl al-Sunnah wa alJamā'ah melazimkan setiap orang sahabat itu adalah adil dan mujtahid.

Kerana itu, Khair Izzah mendakwa Ahl al-Sunnah wa al-Jamā'ah telah mereka-reka hadis semata-mata untuk meletakkan keistimewaan dan kelebihan pada istilah sahabat. Antaranya hadis yang mengumpamakan sahabat seperti bintang, sesiapa yang mengikuti mereka, pasti akan beroleh petunjuk. ${ }^{15}$ Hadis ini didakwa digunakan oleh Ahl

${ }^{14}$ Ibid., 355.

${ }^{15}$ Sanad hadis ini telah dikritik oleh para ulama hadis Ahl al-Sunnah wa al-Jamā'ah sendiri. Ia sebagaimana yang dihuraikan oleh al-Zayla‘ $\overline{\mathrm{i}}$ bahawa hadis yang mengumpamakan sahabat seperti bintang telah diriwayatkan menerusi beberapa riwayat. Antaranya adalah hadis di atas dengan lafaz أصحابي كالنجوم بأيهم اقتنيتم اهتدينم. Namun begitu, kesemua sanad dalam riwayat tersebut terdapat illah tertentu seperti perawi yang majhül, munkar al-hadith dan dituduh pemalsu hadis. Lihat Jamāl al-Dīn 'Abd Allāh bin Yūsuf al-Zayla'i, Takhrīj alAhādith wa al-Āthār al-Wāqi'ah fí Tafsīr al-Kashshāf li alZamakhsharī (Riyāụ: Dār Ibn Khuzaymah, 1414H), 2: 230. Walau bagaimanapun, terdapat hadis-hadis lain yang dinilai sahih oleh Ahl al-Sunnah wa al-Jamā'ah tentang perintah berpegang kepada sahabat. Antaranya hadis yang diriwayatkan oleh al-Tirmidhi bahawa Rasulullah SAW bersabda, "Aku mewasiatkan kamu berpegang kepada para sahabatku, kemudian mereka yang selepas mereka, kemudian mereka yang selepas mereka...". Hadis ini dinilai hasan șahịh gharīb oleh al-Tirmidhi. Manakala al-Hākim mengatakan ia sahih berdasarkan syarat al-Shaykhayn. Hadis riwayat al-Tirmidhi, Kitāb al-Fitan, Bāb Mā Jā’a fī Luzūm al-Jamā'ah, no. hadis: 2165. Lihat Muhammad bin 'Isa, al-Jāmi' al-Șahịh (Beirut: Dār Ihyā' alTurāth al-'Arabì, t.t), 4: 465; al-Hakim, Kitāb al-'Ilm, no. hadis: 387. 
al-Sunnah wa al-Jama'ah untuk menggambarkan kedudukan para sahabat yang dianggap kesemuanya adil. ${ }^{16}$

Menurut Khair Izzah, implikasi daripada definisi tersebut, sesiapa sahaja yang melabelkan para sahabat itu kafir atau murtad, maka tuduhan tersebut akan berbalik kepada dirinya sendiri. Begitu juga sesiapa yang menghina sahabat maka dia juga telah menghina Rasulullah SAW. Kaedah ini telah dipraktikkan oleh Ahl al-Sunnah wa alJamā'ah dalam memperkatakan krisis antara para sahabat dalam perang Jamal dan Șiffīn. Malah konflik yang berlaku antara sahabat dianggap sebagai ijtihad yang sah, jika benar maka dikurniakan dua pahala, adapun sebaliknya dikurniakan satu pahala. Beliau mengatakan:

"Secara ringkasnya, penganut mazhab Sunni berpendapat bahawa semua para sahabat Nabi adalah adil dan saksama. Kesemua mereka adalah sama walaupun darjat mereka berlainan di antara satu sama lain. Sesiapa di kalangan umat yang berani melabelkan para sahabat sebagai kafir murtad, maka tuduhan itu kembali kepada dirinya sendiri. Bahkan sesiapa yang menghina mereka dengan sendirinya ia telah menghina Rasulullah s.a.w. Pandangan umat Sunni yang paling kritikal ialah apa sahaja peristiwa dan kes yang disebutkan dalam paparan sejarah berkaitan peperangan diantara Ali dengan Muawiyah ataupun Aisyah janganlah sekali-kali dibesar-besarkan. Ini adalah kerana segala yang berlaku diantara para sahabat merupakan hasil dari veto ijtihad setiap seorang dari mereka. Jika benar ijtihadnya,

Muḥammad bin 'Abd Allāh al-Ḥakim, al-Mustadrak 'alā al-Ṣaḥiḥayn

(Dār al-Kutub al-'Ilmiyyah, 1990), 1: 160.

${ }^{16}$ Khair Izzah, Meniti Titian Kebenaran, 355. 
maka mereka diberikan satu pahala. Jika salah, maka mereka tidak berdosa." 17

Dalam novel Perempuan Nan Bercinta, Faisal Tehrani turut menggunakan pendekatan yang sama ketika menggunakan istilah sahabat. Beliau dengan jelas sekadar mengertikan sahabat itu adalah orang yang berdamping dan bergaul dengan Rasulullah SAW semasa hayatnya tanpa mempunyai apa-apa kelebihan berbanding Ahl al-Bayt. Kerana itu, beliau beberapa kali membawakan hujah bagaimana para sahabat itu adalah Muslim biasa yang tidak mustahil bersifat munafik, sesat atau murtad hingga menyebabkan mereka tidak layak untuk dijadikan pegangan dan pedoman hidup.

Antaranya Faisal Tehrani mengatakan dalam dialog antara Hashemi dan Dr. Ali Taqi:

"Pengertian yang diberikan oleh Dr. Ali Taqi ini membolehkan kata kafir malah terlekat bukan sahaja kepada orang Muslim, tetapi kepada sahabat Rasulullah yang ingkar kepada baginda." 18

Dalam dialog Mustafa yang merupakan menantu Dr. Ali Taqi, disebutkan kemungkinan sahabat itu menjadi sesat dan murtad. Beliau mengatakan:

"Terdapat hadis Rasulullah s.a.w yang menuntut sahabat baginda dan umat Islam berwaspada kepada 'kesesatan' yang terjadi dalam kalangan sahabat selepas kewafatan baginda. Hadis yang dimaksudkan ialah, 'Daripada Ibnu 'Abbas r.a. Katanya, 'Pada suatu ketika Rasulullah s.a.w berkhutbah memberi pengajaran kepada kami. Sabda beliau, 'Hai sekalian manusia! Kamu semuanya akan dikumpulkan di hadapan Allah tanpa alas

\footnotetext{
${ }^{17}$ Ibid., 356.

${ }^{18}$ Faisal Tehrani, Perempuan Nan Bercinta, 198.
} 
kaki, tanpa pakaian dan tanpa dikhitan. (Bacalah firman Allah), 'Seperti Kami ciptakan pada awal ciptaan, begitulah Kami kembalikan dia, itulah janji Kami yang pasti Kami tepati'. Surah al-Anbiya', ayat 104. Ketahuilah! Makhluk yang mula-mula diberi pakaian pada hari kiamat adalah Ibrahim alaihissalam. Dan ketahuilah, bahawa beberapa umatku akan dihadapkan, lalu mereka ditarik ke kiri. Kataku, 'Wahai Tuhanku! Mereka itu adalah sahabatsahabatku!' Lalu dijawab oleh Allah, 'Engkau tidak tahu apa-apa yang mereka perbuat sepeninggalanmu'. Maka kujawab seperti jawapan hamba Allah yang soleh (Nabi Isa a.s), 'Aku menjadi saksi bagi mereka selama aku berada di antara mereka. Dan Engkau Maha Menyaksikan segala-galanya. Jika Engkau seksa mereka sesungguhnya mereka adalah hamba-hamba-Mu, dan jika Engkau ampuni mereka, sesungguhnya Engkau Maha Perkasa lagi Mala Bijaksana'. Surah al-Ma'idah, ayat 117-118. Lalu dikatakan kepadaku, 'Mereka telah murtad semenjak engkau tinggalkan'."19

Begitu juga dalam dialog Haji Mustafa yang membawa watak pemandu umrah, penulis memberikan gambaran bahawa para sahabat itu sebahagiannya munafik. Beliau mengatakan:

"Justeru, kunjungan jemaah haji ke Madinah tidak lain tidak bukan kerana mendambakan jalan yang lurus dan itu tidak lain tidak bukan terentang antara jasad Rasulullah s.a.w yang mulia di bawah kubah hijau, merangkumi Raudhah yang dipercayai merupakan tempat atau makam Sayidatina Fatimah Zahra. Ini

${ }^{19}$ Ibid., 279-280. 
kerana makam beliau dirahsiakan oleh Sayidina Ali ekoran wasiat Fatimah yang tidak mahu majlis pengebumiannya dihadiri oleh golongan munafik."20

Secara ringkasnya, Faisal Tehrani membawakan sekurang-kurangnya lima hadis sahih yang diriwayatkan oleh Muslim bagi menggambarkan hakikat sahabat. Pertama dan kedua hadis Ibn 'Abbāans' dan 'Uqbah'22 sebagai dalil agar umat Islam berwaspada terhadap kesesatan para sahabat sepeninggalan Rasulullah SAW. ${ }^{23}$ Ketiga, hadis $\mathrm{Jabir}^{24}$ yang memperlihatkan bagaimana sikap ketidaksetiaan para sahabat kepada Nabi SAW. Manakala keempat dan kelima, hadis Abū Sa'id alKhuḍri $^{25}$ dan Ibn Tawūs ${ }^{26}$ yang menunjukkan perbuatan para sahabat mengubah hukum yang telah ditetapkan oleh Rasulullah SAW. ${ }^{27}$

Menerusi hadis-hadis yang dikemukakan itu, Faisal Tehrani ingin mencetuskan persoalan pada minda pembaca, bahawa sahabat hanya manusia biasa yang tidak memiliki apa-apa kelebihan. Istilah sahabat yang digelarkan kepada mereka tidak lebih sekadar merujuk kepada keadaan mereka yang pernah bertemu atau bergaul dengan Nabi

${ }^{20}$ Ibid., 295.

${ }^{21}$ Hadis riwayat Muslim, Kitāb al-Jannah wa Sifah Na‘ỉmihā wa Ahlihā, Bāb Fanā' al-Dunyā wa Bayān al-Ḥashr Yawm al-Qiyāmah, no. hadis: 2860. Lihat Muslim, Șahih Muslim, 4: 2194.

${ }^{22}$ Hadis riwayat Muslim, Kitāb al-Faḍā'īl, Bāb Ithbāt Hawḍ Nabiyyinā șallā Allāh 'alayh wa sallam wa Șifātih, no. hadis: 2296. Ibid., 4: 1796.

${ }^{23}$ Faisal Tehrani, Perempuan Nan Bercinta, 279-280.

${ }^{24}$ Hadis riwayat Muslim, Kitāb al-Jumu'ah, Bāb fī Qawlih Ta'ala, Wa idhā ra'aw tijāratan aw lahwan infaḍụū ilayhā wa tarakūka qā'imā, no. hadis: 863. Ibid., 2: 590.

25 Hadis riwayat Muslim, Kitāb al-Zakāh, Bāb Zakat al-Fitr 'ala alMuslimin min al-Tamr wa al-Sha'ir, no. hadis: 985. Ibid., 2: 678.

${ }^{26}$ Hadis riwayat Muslim, Kitāb al-Zakāh, Kitāb al-Ṭalāq, Bāb Ṭalāq alThalāth, no. hadis: 1472. Ibid., 2: 1099.

${ }^{27}$ Faisal Tehrani, Perempuan Nan Bercinta, 344-345. 
SAW ketika hayat Baginda. Namun, itu bukan jaminan bahawa mereka terlepas daripada melakukan kemaksiatan, kefasikan mahupun kemurtadan seperti golongan yang bukan sahabat.

\section{Etimologi Istilah Sahabat}

Melalui subtopik sebelum ini, dapat difahami bahawa pemahaman kedua-dua penulis tersebut terhadap istilah sahabat berbalik kepada pemikiran Syiah Imāmiyyah Ithnā 'Ashariyyah. Menurut Syiah, para ulama Ahl al-Bayt berpendapat istilah sahabat sama ada șāhib atau aṣhāo dalam bahasa Arab perlu dikekalkan dengan makna dari sudut bahasa dan kebiasaan penggunaannya. Ini kerana, perkataan sahabat bukan istilah yang ditentukan syarak, namun ia sekadar perbendaharaan kata yang wujud dalam bahasa Arab. Bererti, șāhib dalam bahasa Arab tidak memiliki maksud lain kecuali dengan makna mulāzim atau $m u$ 'āshir, iaitu seseorang yang banyak berdamping dengan seseorang yang lain. ${ }^{28}$

Ia sebagaimana perkataan șahiba dalam al-Qur'an yang digunakan untuk merujuk kepada makna mu 'āsharah (pergaulan) dan mulāzamah (perdampingan). Ia sekali-kali tidak digunakan untuk merujuk kepada makna mu 'ạsarah (sezaman) atau ru'yah (penglihatan atau pertemuan) semata-mata. Maka maksud sahabat dari sudut bahasa terikat dengan maksud persahabatan pada tempoh masa yang dipercayai berlaku pergaulan. Ia juga bersifat mutlak dari sudut beriman atau tidak. Ini kerana seseorang yang mendampingi seseorang maka ia boleh dianggap sebagai sahabat walaupun ia tidak mengikutinya dalam soal pemikiran dan akidah. ${ }^{29}$

Oleh kerana perkataan șhbah atau persahabatan ini merujuk kepada perhubungan sekurang-kurangnya dua

${ }^{28}$ Murtaḍā al-'Askarī, Ma 'âlim al-Madrastayn (Iraq: al-Majma' al-'Ilmì al-Islāmí, 1993) 1: 118.

29 Markaz al-Risālah, al-Ṣahābah fī al-Qur'ān wa al-Sunnah wa alTārikh (Qom: Markaz al-Risālah, 1419H), 18. 
orang, maka lafaz șāhib atau kata jamaknya aṣhāb perlu disandarkan kepada nama tertentu dalam percakapan. Ia sepertimana firman Allah SWT dalam surah Yūsuf ayat 39, "șāhibayi al-sijn" bermaksud, "kedua penghuni penjara" dan surah al-Shu'arā' ayat 61, "așhāa $M$ Mūsā" bermaksud "pengikut Nabi Musa". Demikian juga disebut pada zaman Rasulullah SAW, "șāhib Rasūl Allāh" bererti "sahabat Rasulullah" atau "āṣhāb Rasūl Allāh" bermakna "para sahabat Rasulullah". Ini bermakna, perkataan sahabat adalah istilah umum yang tidak semestinya merujuk kepada sahabat Rasulullah SAW secara khusus. Namun begitu, golongan Ahl al-Sunnah wa al-Jama'ah secara perlahanlahan telah menjadikan ia suatu istilah yang merujuk secara khusus kepada para sahabat Rasulullah SAW. ${ }^{30}$

Peristilahan sahabat yang disandarkan kepada Rasulullah SAW itu kemudiannya disandarkan kepada syarak (muștalah al-mutasharri'ah) selepas zaman Rasulullah SAW. Ia dilakukan oleh golongan Ahl alSunnah wa al-Jamā'ah yang menggelarkan sahabat Rasulullah SAW dengan gelaran șaḥa $\bar{b} \bar{i}$ atau $a s ̣ h \bar{a} b$. Oleh yang demikian, ia adalah satu istilah yang direka kemudian dan bukan istilah khas yang diperkenalkan oleh syarak hingga terkait dengan hukum tertentu. ${ }^{31}$

\section{Pendapat Ulama Syiah Mengenai Istilah Sahabat}

Sehubungan itu, terdapat beberapa definisi sahabat menurut pendapat beberapa orang ulama Syiah Imāmiyyah Ithnā 'Ashariyyah. Zayn al-Dīn al-'Āmili, ulama Syiah yang dikenali dengan gelaran al-Shahīd al-Thāni mendefinisikan sahabat sebagai berikut:

"Sahabat itu ialah mereka yang bertemu dengan

Nabi SAW dalam keadaan beriman kepadanya walaupun sesaat sama ada meriwayatkan daripadanya atau tidak, lama bergaul, duduk di

\footnotetext{
${ }^{30}$ Ibid.

31 Ibid.
} 
dalam majlis dengannya atau tidak, mereka berperang bersamanya atau tidak berperang, dan mereka melihatnya sekejap dan tidak duduk disampingnya, dan mereka yang tidak melihatnya (kerana buta seperti Ibn Umm Maktum) dan mati dalam iman dan Islam sekalipun diselangi oleh keadaan murtad, tetapi matinya dalam agama Islam mengikut pendapat yang paling tepat." 32

Ḥujjah al-Islām Ja'far al-Subḥānī pula mengatakan yang masyhur dalam kalangan muhaddithin, sahabat adalah setiap orang yang telah melihat Rasulullah SAW. ${ }^{33}$ Beliau tidak mensyaratkan seseorang sahabat itu semestinya meninggal dunia dalam keadaan Islam.

Murtậa al-Rị̣awì telah mengemukakan pandangan yang lebih jelas dalam mewakili pegangan muktamad Syiah Imāmiyyah Ithnā 'Ashariyyah mengenai definisi sahabat. Beliau telah membincangkan ketiga-tiga pandangan berkenaan kedudukan sahabat, iaitu pandangan Ahl al-Sunnah wa al-Jamā'ah yang mengatakan kesemua para sahabat adalah adil, pandangan kedua yang mengatakan sahabat adalah sama kedudukannya dengan manusia lain dari sudut iman dan amalan, serta pandangan ketiga yang mengatakan semua sahabat telah kafir. ${ }^{34}$

Beliau kemudiannya menyimpulkan, pandangan ketiga adalah tertolak sama sekali kerana tiada sesiapa mengatakan seumpama itu kecuali musuh-musuh Islam. Pandangan pertama pula tidak wajar kerana ia seolah-olah

${ }^{32}$ Zayn al-Din al-'Āmilì, al-Dirāyah fì 'Ilm al-Hadìth (Iran: Manshūrat Maktabah al-Mufid, t.t), 120.

33 Ja'far al-Subḥānī, Ușūl al-Hadìth wa Aḥkāmuhu fī 'Ilm al-Dirāyah (Qom: Dar Jawwad, 2012), 125.

${ }^{34}$ Murtaḍa al-Riḍawī, Arā' al- 'Ulamā' al-Muslimīn fī al-Taqiyyah wa al-Ṣahābah wa Șiyānah al-Qur'ān al-Karīm (Beirut: al-Irshād li alȚibā'ah wa al-Nashr, t.t), 107; Khair Izzah, Meniti Titian Kebenaran, 352. 
menjadikan sahabat itu maksum dan terlepas segala taklif ke atas mereka. Justeru, yang berbaki adalah pandangan kedua, iaitu pandangan pertengahan sebagaimana yang dipegang oleh golongan Syiah dengan meletakkan kedudukan sahabat itu bergantung kepada iman dan amalannya sendiri. ${ }^{35}$

Berdasarkan kaedah tersebut, al-Riḍawi berpendapat sifat persahabatan (suhbah) itu umum bagi sesiapa yang bersahabat dengan Nabi SAW atau melihatnya atau mendengar hadisnya. Ia meliputi yang mukmin, munafik, adil, fasik, baik atau jahat. Ia sebagaimana yang berlaku kepada Rasulullah SAW dalam peristiwa perang Tabuk apabila terdapat golongan munafikin yang mempertikaikan Baginda. Sa'd bin 'Ubādah lantas menawarkan diri untuk membunuh golongan munafikin tersebut namun ditolak oleh Rasulullah SAW. Baginda bimbang jika manusia akan berkata bahawa Muhammad telah membunuh para sahabatnya. ${ }^{36}$ Dengan itu, persahabatan semata-mata tidak melayakkan para sahabat untuk dianggap adil. Malah,

35 Al-Riḍawì, Arā' al- 'Ulamā' al-Muslimīn, 107.

${ }^{36}$ Kisah ini diriwayatkan oleh al-Mawardi dalam A 'lām al-Nubuwwah, bahawa ketika Rasulullah SAW dan tentera muslimin dalam perjalanan ke Tabuk, mereka mengalami kehausan sedangkan kawasan air langsung tidak ditemui. Baginda telah mengutuskan Abū Qatādah, Abū Țalḥah, Sammāk bin Kharshah dan Sa'd bin 'Ubādah untuk mencari air. Namun mereka tidak berjaya mencarinya. Nabi SAW sekali lagi mengutuskan Usayd bin Khuḍayr dan Usāmah untuk mencari air daripada golongan A'rāb, lantas golongan munafikin berkata, "Sesungguhnya Muhammad itu diberitakan dengan berita langit, tetapi dia tidak mengetahui jalan menuju ke air?" Hal ini dikhabarkan oleh Jibril kepada Nabi SAW, lalu Baginda mengadukannya kepada Sa'd bin 'Ubādah. Sa'd berang sambil meminta izin kepada Nabi SAW untuk memenggal leher golongan munafiqin itu. Baginda menegah lalu bersabda, "Supaya orang ramai tidak mengatakan Muhammad telah membunuh sahabatnya, tetapi kita berbuat baik dalam bersahabat dengan mereka selagimana mereka bersama-sama dengan kita." Lihat 'Ali bin Muhammad al-Mawardi, A 'lām al-Nubuwwah (Beirut: Dār al-Kitāb al-'Arabìi, 1987), 158-159. 
kedudukan mereka berbeza-beza berdasarkan darjat iman dan amalan masing-masing. ${ }^{37}$

Seorang ulama Syiah kontemporari, 'Alì al-Husayni al-Mīlāni berpendapat, tiada yang membezakan definisi sahabat dari sudut bahasa dan istilah kecuali Islam. Menurut beliau, pendapat ini disepakati bersama oleh Ahl al-Sunnah wal a-Jamā'ah dan Syiah. ${ }^{38}$ Ia berdasarkan definisi sahabat menurut Ibn Hajar al-'Asqalānī yang mengatakan sahabat adalah orang yang bertemu dengan Rasulullah SAW, beriman dengannya dan meninggal dunia dalam keadaan Islam. ${ }^{39}$

Al-Mìlānì mengatakan, takrifan Ibn Hajar ini adalah sangat umum hingga golongan munafikin juga termasuk dalam kalangan sahabat. ${ }^{40}$ Walaupun demikian, definisi tersebut bertepatan dengan hadis Rasulullah SAW yang menyifatkan ketua golongan munafikin iaitu 'Abd Allāh bin Ubay bin Salūl sebagai sahabat. ${ }^{41}$ Dengan itu, al-Mīāni

${ }^{37}$ Al-Riduawì, Arā' al- 'Ulamā' al-Muslimīn, 108.

38 'Alī al-Husayni al-Mīlāni, al-Ṣaḥābah, (Qom: Markaz al-Abhath al'Aqā'idiyyah, 1421H), 12.

${ }^{39}$ Ibn Hajar al-'Asqalani, al-Ișābah, 1: 6.

40 Al-Mīiāni, al-Ṣaḥābah, 13.

${ }^{41}$ Ia berdasarkan kisah yang diriwayatkan oleh Ibn Sa‘d. Ketika dalam perjalanan pulang daripada peperangan Bani Mustaliq, berlaku sedikit ketegangan antara golongan Anșār dan Muhājirīn ketika mengambil air di mata air. Hal ini kemudiannya didamaikan oleh Rasulullah SAW, namun ketua munafiqin, 'Abd Allāh bin Ubay bin Salūl memberi komentar dengan mengatakan, "Demi Allah, jika kita telah kembali ke Madinah, maka penduduknya yang mulia akan benarbenar mengusir penduduknya yang hina." Ungkapan ini didengar oleh Zayd bin Arqam, lalu beliau menyampaikannya kepada Rasulullah SAW sehingga turut diketahui oleh anak Ibn Ubay iaitu 'Abd Allāh. Lalu ketika perjalanan ingin diteruskan, 'Abd Allāh bin 'Abd Allāh bin Ubay telah menahan bapanya sambil berkata, "Aku tidak akan meninggalkan kamu sehingga kamu menganggap kamu itu hina sedangkan Muhammad itu mulia." Apabila Rasulullah SAW melewatinya, Baginda bersabda, "Maka demi umurku, kita akan berbuat baik dalam bersahabat dengannya selagimana dia berada 
berpendapat takrifan sahabat yang dikemukakan oleh Ibn Hajar mencakupi golongan munafik, mukmin, baik, jahat, yang meriwayatkan daripada Baginda atau tidak dan yang bergaul rapat dengan Baginda atau tidak.

Ini kerana, yang dimaksudkan daripada takrifan Ibn Hajar itu hanya sekadar pertemuan dengan Nabi SAW atau melihat Baginda. ${ }^{42}$ Al-Dawkhi turut menyokong pendapat ini, beliau mengatakan menerusi takrifan Ibn Hajar tersebut, munafik juga termasuk dalam erti kata șaḥa $\bar{b} \bar{i}$. Ini kerana munafik adalah orang yang menzahirkan keimanan dan menyembunyikan kekufuran, justeru seseorang munafik yang menzahirkan keimanan dan bertemu dengan Baginda ketika hayatnya adalah termasuk dalam erti kata sahabat. $^{43}$

Berdasarkan perbahasan di atas, dapat disimpulkan bahawa kedua-dua penulis cenderung mendefinisikan sahabat dengan definisi yang diberikan dari sudut bahasa menurut perspektif Syiah Imāmiyyah Ithnā 'Ashariyyah. Perkataan sahabat bukan istilah yang ditentukan syarak, namun ia sekadar perbendaharaan kata yang wujud dalam bahasa Arab yang digunakan secara umum sama ada dalam al-Qur'an mahupun hadis. Pun begitu, ia telah menjadi satu istilah khas yang direka kemudian oleh golongan Ahl alSunnah wa al-Jamā'ah dan bukan istilah yang diperkenalkan oleh syarak hingga terkait dengan hukum tertentu. Oleh yang demikian, Syiah mendefinisikan sahabat sebagai istilah umum bagi sesiapa yang bersahabat dengan Nabi SAW atau melihatnya atau mendengar hadisnya tanpa mengira ia mukmin, munafik, murtad, adil, fasiq, baik atau jahat.

dalam kalangan kita." Lihat Muhammad bin Sa'd, al-Tabaqāt alKubrā (Beirut: Dar Șādir, t.t), 2: 65.

42 Al-Mīlāni, al-Ṣahāàah, 13.

43 Yahyā bin 'Abd al-Muhsin al-Dawkhī, 'Adālah al-Ṣahābah bayn alQadāsah wa al-Wāqi' (Iran: al-Majma' al-'Ālamí li Ahl al-Bayt, 1430H), 37-38. 


\section{Definisi Sahabat menurut Ahl al-Sunnah wa al- Jamā'ah}

Dalam memahami pengertian sahabat, Ahl al-Sunnah wa al-Jamā'ah membahaskannya secara komprehensif dan menyeluruh. Ia tidak terhad memberikan maksud kepada istilah sahabat semata-mata. Kesilapan Syiah Imāmiyyah Ithnā 'Ashariyyah apabila sekadar membahaskan istilah sahabat dan perkaitannya dari sudut bahasa Arab sematamata. Walhasil, ia memberikan tanggapan yang tidak lengkap terhadap konsep sahabat itu sendiri. Bagi Ahl alSunnah wa al-Jamā'ah, definisi sahabat dibincangkan secara tuntas dengan melihat kepada definisi bahasa dan istilah, berasaskan indikator yang diisyaratkan oleh alQur'an dan al-Sunnah. Hanya menerusi perbahasan yang menyeluruh, seseorang akan dapat memahami konsep sahabat yang tepat.

Dari sudut etimologi, tidak berlaku perbezaan antara Ahl al-Sunnah wa al-Jamā'ah dan Syiah Imāmiyyah Ithnā 'Ashariyyah mengenai asal perkataan sahabat. Menurut Abū Bakr al-Khațíb, tiada khilaf antara ahli bahasa bahawa perkataan șahābi berasal daripada perkataan șuhbah. Ia tidak terikat dengan kadar yang tertentu bahkan disebut bagi setiap yang bergaul dengan yang lain, sama ada dengan kadar sedikit atau banyak, lama atau sebentar. Ia sebagaimana perkataan mukallim (yang berkata-kata), mukhātib (yang berucap) dan d̦ārib (yang memukul) yang berasal daripada perkataan mukālamah, mukhātabah dan darb yang disebut sedemikian tanpa mengambil kira sama ada sedikit atau banyak, lama atau sebentar.

Bererti, perkataan sahabat juga digunakan tanpa mengira banyak atau sedikit, lama atau sebentar, seperti mengatakan, "șahibtu fulānan sanatan, wa shahran, wa yawman, wa sā 'tan" (aku bersahabat dengan fulan, setahun, sebulan, sehari, sejenak). Justeru, termasuk dalam erti kata 
sahabat dari sudut bahasa, orang yang bergaul dengan Nabi SAW walaupun sebentar. ${ }^{44}$

Perbezaan ketara berlaku antara Ahl al-Sunnah wa alJamā'ah dan Syiah Imāmiyyah Ithnā 'Ashariyyah dalam membicarakan definisi sahabat dari sudut istilah. Walau bagaimanapun, jika diteliti secara mendalam, perbezaan tersebut bukan berpunca daripada perbezaan dalam memahami istilah sahabat semata-mata, sebaliknya ia lebih kepada perbezaan dalam memahami epistemologi sahabat.

Ini kerana, Syiah Imāmiyyah Ithnā 'Ashariyyah pada peringkat awal, mendakwa Ibn Hajar yang mewakili Ahl alSunnah wa al-Jamā'ah terlalu longgar dalam mendefinisikan istilah sahabat sehingga memasukkan semua orang yang pernah hidup pada zaman Rasulullah SAW tanpa seorang pun terkecuali. Sedangkan takrifan yang dikemukakan oleh Ibn Hajar adalah takrifan yang hampir sama dari sudut bahasa sebagaimana juga ditakrifkan oleh golongan Syiah Imāmiyyah Ithnā 'Ashariyyah. Malah dalam Ahl al-Sunnah wa al-Jamā'ah sendiri, terdapat perbezaan dalam mendefinisikan sahabat antara pihak muhaddithin dan pihak fuqahā'dan usuliyyin.

Kumpulan muhaddithin berpegang dengan takrifan yang dikemukakan oleh Ibn Hajar, bahawa sahabat adalah seseorang yang bertemu dengan Nabi SAW secara sedar, beriman selepas kebangkitan Baginda sebagai nabi, ketika Baginda masih hidup dan meninggal dunia dalam keadaan beriman. ${ }^{45}$ Manakala jumhur fuqahā'dan usuliyyīn pula mendefinisikan sahabat sebagai orang yang bertemu dengan Nabi SAW secara sedar, beriman selepas kebangkitan Baginda, ketika Baginda masih hidup, lama persahabatan dengan Baginda, banyak pertemuan dengan

44 Abū Bakr al-Khațīb al-Baghdādi, al-Kifāyah fī 'Ilm al-Riwāyah (Madinah: al-Maktabah al-'Ilmiyyah, t.t), 51; Muhammad bin 'Abd al-Raḥmān al-Sakhāwī, Fath al-Mughìth Sharh Alfiyah al-Hadìth (Beirut: Dār al-Kutub al-'Ilmiyyah, 1403h), 3: 94.

45 Ibn Hajar al-'Asqalānì, al-Iṣābah fī Tamyìz al-Ṣaḥābah, 1: 6. 
Baginda dengan maksud mengikut dan mengambil riwayat daripada Baginda walaupun tidak meriwayatkan sesuatu pun daripada Baginda dan meninggal dunia dalam keadaan beriman. ${ }^{46}$

Perbezaan antara kedua-dua pihak adalah berpunca daripada perbezaan dalam mentakrifkan sahabat dari sudut bahasa dan 'uruf. Golongan muhaddithīn mendefinisikan sahabat dengan meraikan sudut bahasa yang umum, tanpa mengambil kira lama atau singkatnya persahabatan itu. Manakala golongan fuqahā' dan uṣuliyyín pula mendefinisikan sahabat berdasarkan 'uruf kerana pada kebiasaannya sebutan sahabat itu merujuk kepada orang yang lama tempoh persahabatannya. ${ }^{47}$

Walau bagaimanapun, perbezaan yang berlaku antara pihak muhaddithīn dan pihak fuqahā' dan uṣūliyyīn ini bukan perbezaan yang bersifat kontradik (ta'addud ta'ārud), sebaliknya ia perbezaan yang bersifat variatif (ta'addud tanawwu') kerana lapangan perbahasan yang berbeza. Jika diteliti, takrifan sahabat bagi muhaddithin berkaitan langsung dengan keadilan para sahabat dan penerimaan periwayatan mereka. Sedangkan pengertian sahabat menurut fuqahā' dan ușüliyyīn adalah perbincangan berkaitan pendapat para sahabat sebagai hujah (hujjiyyah qawl al-șaḥa bi ) yang memerlukan syaratsyarat seperti berada bersama dan mendengar wahyu pada ketika ia turun, mengetahui yang nāsikh dan mansūkh, am

\footnotetext{
46 'Umar bin 'Alī al-Anșāī, al-Muqni' fí 'Ulūm al-Hadīth (Saudi: Dār Fawwāz, 1413h), 2: 491; al-Sakhāwì, Fath al-Mughìth Sharh Alfiyah al-Hadīth, 3: 93; 'Uthmān bin 'Abd al-Rahmān al-Shahrazūrī, Muqaddimah Ibn al-Șalāh fí 'Ulūm al-Hadìth (Beirut: Dār al-Fikr alMu'așir, 1977), 291.

${ }^{47}$ Abū al-Ma'āli al-Juwayni, al-Talkhīs fī Ușūl al-Fiqh (Beirut: Dār alBashā'ir al-Islāmiyyah, 1997), 2: 414; Abū al-Muẓaffar al-Sam'ānī, Qawāṭi' al-Adillah fī al-Ușūl (Beirut: Dār al-Kutub al-'Ilmiyyah, 1997), 1: 392; Abū Ḥāmid al-Ghazālì, al-Mustașfā fī 'Ilm al-Uṣūl (Beirut: Dār al-Kutub al-'Ilmiyyah, 1413h), 131.
} 
dan khas dan lain-lain yang tidak mungkin diperolehi kecuali dengan lamanya pergaulan dengan Nabi SAW. ${ }^{48}$

Ini bererti, takrifan yang dikemukakan oleh pihak muhaddithin lebih umum dan mencakupi takrifan pihak

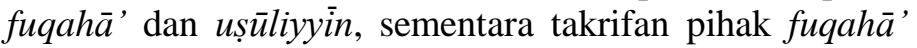
dan uṣüliyyin pula lebih khusus. Oleh sebab itu, tiada pertentangan antara kedua-dua pihak dalam memperakui keadilan para sahabat. Bahkan ia dinukilkan sebagai ijmak para ulama Ahl al-Sunnah wa al-Jamā'ah. ${ }^{49}$

\section{Kritikan terhadap Definisi Sahabat menurut Syiah}

Berbalik kepada definisi sahabat menurut pemahamanan Syiah sebagaimana disebutkan pengkaji sebelum ini, punca perbezaan adalah pada epistemologi dalam memahami sahabat. Bukan berpunca daripada takrifan sahabat menurut Ahl al-Sunnah wa al-Jamā'ah yang didakwa terlampau longgar. Ini kerana, Syiah Imāmiyyah Ithnā 'Ashariyyah sendiri menolak kewujudan maksud sahabat dari sudut istilah syarak dan sekadar memaknakan perkataan sahabat secara literal. Dalam masa yang sama memanipulasi takrifan sahabat yang didakwa longgar dengan memasukkan ke dalam erti kata sahabat golongan yang murtad, munafik, fasik dan pelaku maksiat. Walhal, Ahl alSunnah wa al-Jamā'ah tidak sekali-kali mengatakan golongan sedemikian sebagai tergolong dalam kalangan sahabat.

Pada hakikatnya, penolakan Syiah Imāmiyyah Ithnā 'Ashariyyah terhadap takrifan Ahl al-Sunnah wa alJamā'ah adalah berpunca daripada penyandaran perkataan sahabat sebagai suatu istilah khas yang berdalilkan alQur'an dan al-Sunnah. Sedangkan, Syiah Imāmiyyah Ithnā 'Ashariyyah mengekalkan istilah sahabat pada makna bahasa yang tidak memberikan apa-apa makna yang

\footnotetext{
48 'Abd al-Raḥmān bin 'Abd Allāh al-Sha'lān, Ușūl Fiqh al-Imām Mālik: Adillatuh al-Naqliyyah (Riyaḍ: Jāmi'ah al-Imām Muḥammad bin Su'ūọ al-Islāmiyyah), 2: 1108;

${ }^{49}$ Al-Shahrazūrì, Muqaddimah Ibn al-Ṣalāh fì 'Ulūm al-Hadìth, 294.
} 
signifikan dari sudut syarak. Ahl al-Sunnah wa al-Jamā'ah berpandangan, iktikad Syiah Imāmiyyah Ithnā 'Ashariyyah yang mendakwa istilah sahabat sebagai muștalah almutasharri 'ah adalah tertolak. Ini kerana, terdapat banyak dalil yang menunjukkan bahawa ia suatu istilah yang disyariatkan berdasarkan nas-nas syarak.

Bagi Ahl al-Sunnah wa al-Jamā'ah, perkataan sahabat apabila disandarkan kepada Nabi SAW, ia merupakan istilah khusus yang didasarkan kepada kemuliaan kedudukan Nabi SAW itu sendiri. Dengan melihat sendiri cahaya kenabian Nabi Muhammad SAW, ia mencetuskan suatu keyakinan yang kukuh di dalam hati seseorang mukmin sehingga kesannya terlihat pada anggota zahir lalu menjadikan orang yang melihat sentiasa berada dalam ketaatan sepanjang hayat. $^{50}$ Ia sebagaimana sabda Rasulullah SAW:

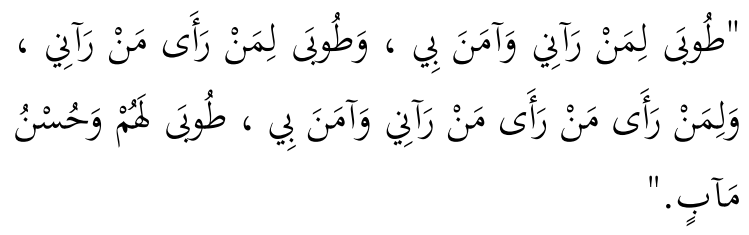

Terjemahan:

"Berbahagialah bagi sesiapa yang melihatku, beriman denganku, dan berbahagialah bagi sesiapa yang melihat orang yang melihatku, (dan berbahagia) juga sesiapa yang melihat orang yang melihat orang yang melihatku dan beriman denganku, berbahagialah mereka dan (bagi mereka) sebaik-baik tempat kembali." ${ }^{, 51}$

50 'Alī bin 'Abd al-Kāfī al-Subkī, al-Ibhāj fī Sharh al-Minhāj (Beirut: Dār al-Kutub al-'Ilmiyyah, 1404H), 1: 15.

${ }^{51}$ Hadis riwayat al-Hākim, Zikr Faḍā'il al-Ummah ba'd al-Ṣahābah wa al-Tābi‘īn, no. hadis: 6994. Lihat al-Mustadrak 'alā al-Ṣahịhayn, 4: 94; Ibn Hibban, Kitab Ikhbaruh salla Allah 'alayh wa sallam 'an Manaqib al-Sahabah, Bab Faḍl al-Ummah, no. hadis: 7230. Lihat Muḥammad bin Hibbān, Șaḥih ibn Hibbān bi Tartīb Ibn Balbān 
Demikian juga hadis Wāthilah bin al-Asqa', bahawa Rasulullah SAW bersabda:

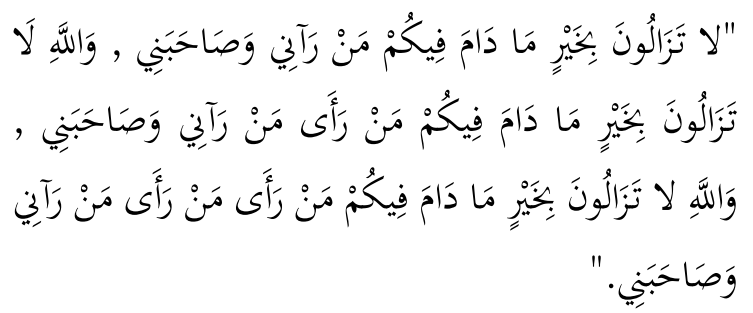

Terjemahan:

"Kamu akan sentiasa dalam keadaan baik selagi mana dalam kalangan kamu orang yang melihatku dan bersahabat denganku. Demi Allah, kamu sentiasa dalam keadaan baik selagi mana dalam kalangan kamu orang yang melihat orang yang melihatku dan bersahabat denganku. Demi Allah, kamu sentiasa dalam keadaan baik selagi mana dalam kalangan kamu orang yang melihat orang yang melihat orang yang melihatku dan bersahabat denganku." 52

Manakala perkataan "sahabatku" kerap kali digunakan oleh Rasulullah SAW dalam hadis-hadis Baginda. Antaranya adalah hadis ' $\overline{\mathrm{A}}$ 'ishah r.a.h seperti berikut:

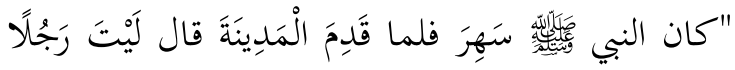

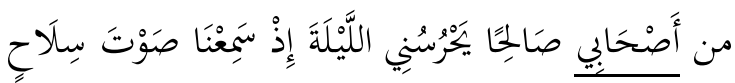

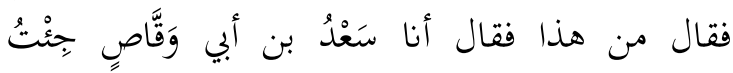

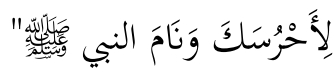

(Beirut: Mu'assasah, 1993), 16: 213. Menurut Shu'ayb al-Arna'ūt hadis ini hasan li ghayrih.

${ }^{52}$ Hadis riwayat al-Muttaqi al-Hindi, no. hadis: 32504. Lihat 'Alā' alDin 'Alì al-Muttaqqi al-Hindi, Kanzl al- 'Ummāl fi Kanz fī Sunan alAqwāl wa al-Af'āl (Beirut: Dār al-Kutub al-'Ilmiyyah, 1998), 11: 244. Beliau mengatakan hadis ini sahih. 
Terjemahan:

"Nabi SAW tidak dapat tidur pada malam hari ketika mula-mula sampai ke Madinah. Baginda bersabda: Alangkah baik jika ada seorang yang soleh daripada kalangan para sahabatku berjaga-jaga untukku malam ini. Tiba-tiba kami terdengar bunyi senjata. Lalu Baginda bersabda: Siapa ini? Lalu berkata: Aku Sa'd bin Abī Waqqāṣ, aku datang berjaga-jaga untukmu. Selepas itu Nabi SAW pun tidur." 53

Antaranya juga doa Nabi SAW kepada para sahabat Baginda yang berhijrah dari Makkah ke Madinah. Baginda berdoa:

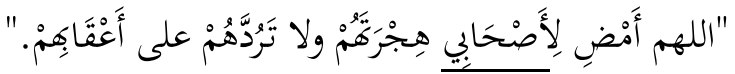

Terjemahan:

"Wahai Allah, tetapkanlah buat para sahabatku penghijrahan mereka, jangan Engkau kembalikan mereka kepada keadaan asal mereka (sebelum hijrah)." ${ }^{54}$

Begitu juga hadis Anas bin Mālik ketika Baginda SAW menjemput mereka untuk makan bersama seperti berikut:

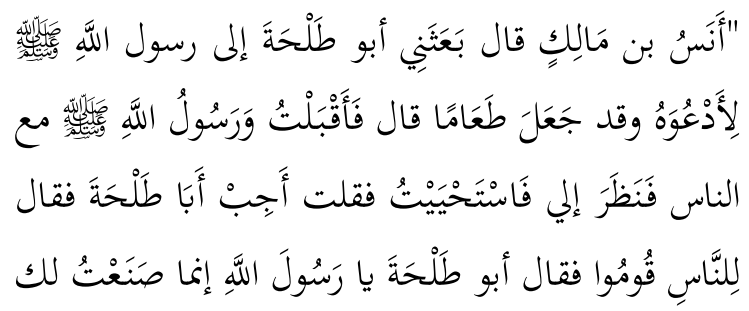

${ }^{53}$ Hadis riwayat al-Bukhārī, Kitāb al-Jihād wa al-Siyar, Bāb al-Hirāsah fī al-Ghuzuw fī Sabīl Allāh, no. hadis: 2729. Lihat al-Jāmi 'al-Ṣaḥịh al-Mukhtașar, 3: 1057.

${ }^{54}$ Hadis riwayat al-Bukhārī, Kitāb Faḍā'il al-ṣahābah, Bāb Qawl al-Nabī Allahumma amḍi li aṣhābi hijratahum, no. hadis: 3721. Lihat al-Jāmi * al-Șahịh al-Mukhtaṣar, 3: 1431. 


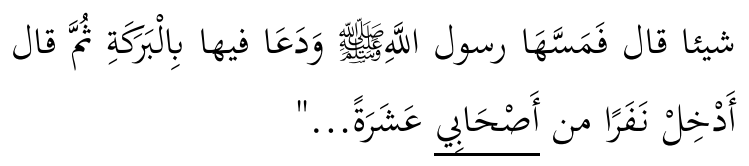

Terjemahan:

"Abū Talhah telah mengutuskan aku kepada Rasulullah SAW supaya menjemput Baginda kerana beliau telah menyediakan makanan. Beliau (Anas bin Mālik) berkata: Aku bertemu dan Rasulullah SAW sedang bersama-sama orang ramai. Lalu Baginda melihatku hingga aku berasa malu. Lalu aku berkata: Penuhilah (jemputan) Abū Ṭalḥah. Baginda menyeru kepada orang ramai: Bangunlah. Lalu Abū Țalhahah berkata: Wahai Rasulullah, aku membuat sedikit sahaja makanan untuk kamu. Beliau (Anas bin Mālik) berkata: Lalu Rasulullah SAW menyentuh makanan itu, mendoakannya dengan keberkatan kemudian bersabda: Masuklah sepuluh orang daripada para sahabatku..." 55

Selain itu hadis Sa‘ijd bin Abi Burdah yang merujuk para sahabat Baginda SAW sebagai penjaga umat ini seperti berikut:

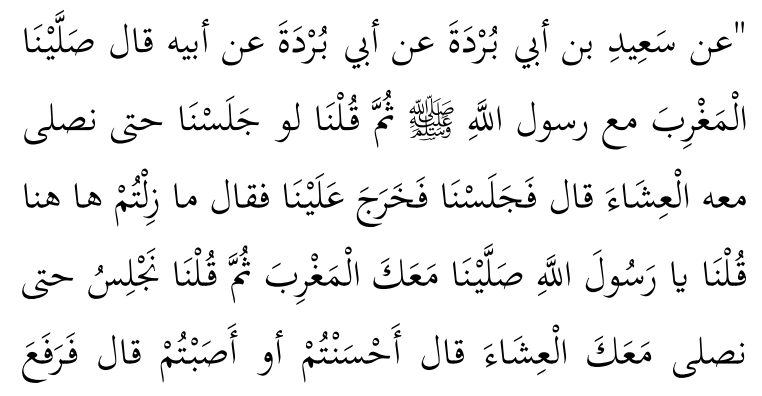

55 Hadis riwayat Muslim, Kitāb al-Ashribah, Bāb Jawāz Istitbā‘ihi ilā Dār Man Yathiq bi Riḍāh, no. hadis: 2040. Lihat Ṣahịh Muslim, 3: 1612. 


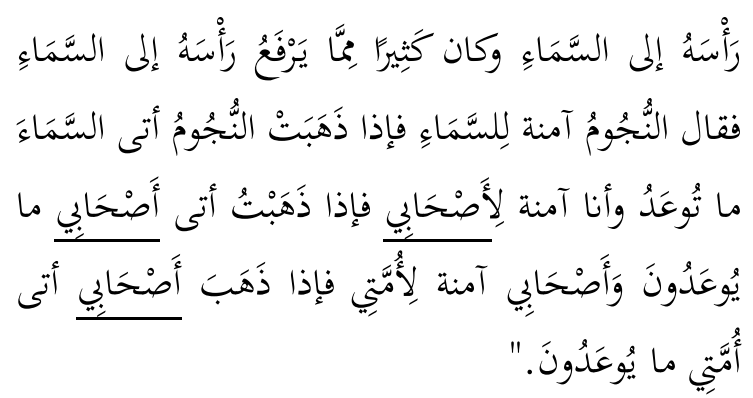

Terjemahan:

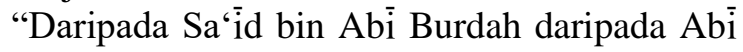
Burdah daripada bapanya, beliau berkata: Kami solat Maghrib bersama-sama Rasulullah SAW kemudian kami berkata: (Lebih baik) kita duduk sehingga kita solat Isyak bersama Baginda. Beliau berkata: Kami duduk, lalu Baginda keluar menemui kami. Baginda menyapa: Kamu masih di sini? Kami menjawab: Wahai Rasulullah kami bersolat Maghrib bersama-samamu, kemudian kami berkata, kita duduk hingga kita bersolat Isyak bersama-samamu. Baginda membalas: Kamu benar. Beliau berkata: Lalu Baginda mengangkat kepalanya ke langit, sedangkan Baginda banyak kali mengangkat kepala Baginda ke langit sambil berkata: Bintangbintang penjaga bagi langit, apabila pergi bintang-bintang, maka datanglah kepada langit apa yang dijanjikan. Dan aku penjaga bagi para sahabatku, maka apabila aku pergi, datanglah kepada para sahabatku apa yang dijanjikan buat mereka. Dan para sahabatku penjaga bagi umatku, maka apabila pergi para sahabatku, 
datanglah kepada umatku apa yang dijanjikan kepada mereka." 56

Banyak lagi hadis yang menunjukkan bahawa Rasulullah SAW sendiri kerap kali menggunakan lafaz "sahabatku" bagi merujuk kepada mereka yang berdampingan dengan Baginda secara khusus. Namun demikian, sekadar mengetahui penggunaan lafaz sahabat oleh Nabi SAW adalah tidak memadai kerana ia masih tidak mampu memberikan gambaran yang komprehensif dan lengkap mengenai istilah sahabat.

Gambaran yang tidak lengkap mengenai sahabat menjadi punca golongan Syiah Imāmiyyah Ithnā 'Ashariyyah memasukkan ke dalam istilah sahabat sesiapa sahaja yang bersua dengan Nabi SAW termasuk orang munafik dan murtad. Hal ini disebabkan Syiah Imāmiyyah Ithnā 'Ashariyyah tidak membezakan pengertian sahabat dari segi istilah dan bahasa. Sedangkan, dari sudut bahasa Arab, perkataan sahabat mempunyai pengertian dan fungsi yang amat luas. Sekurang-kurangnya ia boleh dinyatakan seperti berikut $^{57}$ :

a. Al-Șhbah al-Majāziyyah: Ia digunakan pada dua perkara berbeza yang antara kedua-duanya terdapat sifat yang sama, walaupun antara kedua-duanya jarak masa yang jauh. Ia seperti sabda Rasulullah SAW ${ }^{58}$ yang menyamakan sifat ' $\bar{A}$ 'ishah dengan Zulaykhā', "Sesungguhnya kamu, seperti șawāhib Yūsuf."

56 Hadis riwayat Muslim, Kitāb Faḍā'il al-Ṣahābah, Bāb Bayān anna Baqā' al-Nabī Amān li Aṣhābih wa Baqā' Aṣhābih Amān li alUmmah, no. hadis: 2531. Lihat Șahị Muslim, 4: 1961.

57 'Abd Allāh Jarwān al-Khuḍayr, Mà Qālah al-Thaqalān fí Awliyā' alRaḥmān (Kuwait: Mabarrah al-Āl wa al-Aṣhāo, 2007), 17-18.

${ }^{58}$ Hadis riwayat al-Bukhārī, Kitāb al-Jamā‘ah wa al-Imāmah, Bāb Ḥadd al-Marị̣ an Yashhad al-Jamā'ah, no. hadis: 633. Lihat al-Jāmi' alȘahịh al-Mukhtașar, 1: 236.

59 Bentuk persamaan antara kedua-dua mereka adalah Zulaykhā telah menjemput para wanita Mesir dan menzahirkan seolah-olah beliau ingin memberikan penghormatan kepada mereka, padahal tujuannya 
b. Al-Ṣuhbah al-Iḍ̂afiyyah: Ia disebut untuk menyandarkan kepada sesuatu yang mempunyai perkaitan seperti șăhị 'ilm (orang berilmu) dan șăḥib $m \bar{a} l$ (pemilik harta).

c. Șuḥbah al-Qā'im bi al-Mas'ūliyyah: Ia digunakan untuk merujuk kepada pelaksana tanggungjawab. Contohnya seperti firman Allah SWT, "Dan (ketahuilah bahawa hikmat) Kami tidak menjadikan pengawal-pengawal neraka (aṣhāo al-nār) itu melainkan (dari kalangan) malaikat..." (Surah alMuddaththir: 31)

d. Suhbah al-Luqyā: Ia digunakan untuk merujuk kepada pertemuan yang berlaku antara dua orang walaupun sekali atas sebab tertentu, kemudian terputus. Ia sebagaimana hadis berkenaan khiyār jual beli. Sabda Rasulullah SAW: "Penjual dan pembeli memiliki pilihan selagi mana kedua-duanya belum berpisah, atau berkata salah seorang kepada sahabatnya (sāhibih): pilihlah..."60

e. Suhbah al-Mujāwarah: Ia digunakan untuk merujuk kepada perbualan antara dua orang tanpa mengira sama ada mukmin atau kafir sebagaimana firman Allah SWT dalam surah al-Kahf: 37: "Berkatalah sahabatnya kepadanya, semasa dia berbincang

adalah supaya mereka melihat sendiri kecantikan Yūsuf lalu mereka akan memahami bagaimana ia membuatkannya jatuh cinta kepada Yūsuf. Hal ini sama dengan keadaan ' $\bar{A}$ 'ishah yang menzahirkan sikap beliau menolak perintah Nabi SAW agar bapanya menjadi imam solat dengan alasan khuatir jika makmum tidak dapat mendengar suara bapanya akibat tangisan. Padahal tujuan sebenar di sebalik penolakan ' $\bar{A}$ 'ishah supaya kelak orang tidak mempertikaikan bapanya dan ingin benar-benar memastikan bahawa tiada orang lain yang paling disukai oleh Rasulullah SAW untuk menggantikan tempat Baginda kecuali Abū Bakr. Lihat Aḥmad bin 'Alì bin Hajar al'Asqalānī, Fath al-Bārí Sharh Șaḥịh al-Bukhārī (Beirut: Dār Ma'rifah, t.t), 2: 153.

${ }^{60}$ Hadis riwayat al-Bukhārī, Kitāb al-Buyū', Bāb Idhā Lam Yūqat fī alKhiyār Hal Yajūz al-Bay', no. hadis: 2003. Ibid, 2: 743. 
dengannya: Patutkah engkau kufur ingkar kepada Allah yang menciptakan engkau dari tanah, kemudian dari air benih, kemudian Dia membentukmu dengan sempurna sebagai seorang lelaki?"

f. Perkataan sahabat juga digunakan untuk orang yang tidak dikenali dan tidak pernah ditemui. Misalnya kata-kata 'Abd al-Raḥmān bin 'Awf kepada dua orang kanak-kanak Anșār yang sedang mencari Abū Jahl untuk membunuhnya ketika perang Badar, "Ini (Abū Jahl) sahabat kamu berdua yang kamu sedang mencarinya." 61

Berdasarkan pengertian sahabat menurut bahasa di atas, ia menunjukkan penggunaannya adalah sangat umum. Jika ia digunakan untuk merujuk kepada sahabat Rasulullah SAW, sudah tentu umat terkemudian juga termasuk dalam erti kata sahabat, apatah lagi orang Yahudi, Nasrani, munafikin dan musyrikin yang sempat bertemu dengan Nabi SAW ketika hayat Baginda. Ini disebabkan, sahabat dari sudut bahasa tidak mensyaratkan beriman dengan Baginda dan meninggal dunia dalam keadaan beriman.

Namun begitu, Syiah Imāmiyyah Ithnā 'Ashariyyah mengeskploitasi takrifan bahasa tersebut untuk memasukkan sesiapa sahaja termasuk orang munafik dan murtad ke dalam erti kata sahabat Rasulullah SAW. Antara hadis-hadis yang sering dijadikan dalil sebagai hujah menyokong dakwaan mereka adalah hadis Jābir bin 'Abd Allāh mengenai pertelingkahan antara golongan Ansar dan Muhajirin, lalu diambil kesempatan oleh 'Abd Allāh bin Ubay untuk menghasut golongan Anșār agar menghalau golongan Muhajirin dari Madinah. Apabila hal ini sampai ke pengetahuan Rasulullah SAW, 'Umar dengan pantas memohon izin untuk membunuh 'Abd Allāh bin Ubay,

${ }^{61}$ Hadis riwayat al-Bukhārī, Kitāb al-Jihād wa al-Siyar, Bāb Man Lam al-Aslāb wa Man Qatala Qatīlan Falah Salabuh Min Ghayr an Yukhammis wa Hukm al-Imām fih, no. hadis: 2972. Lihat al-Jāmi * al-Ṣahịh al-Mukhtaṣar, 3: 1144. 
namun Baginda menjawab, "Biarkan dia, agar orang ramai tidak mengatakan Muhammad membunuh para sahabatnya."62

Hadis lain yang juga sering dijadikan hujah oleh pihak Syiah Imāmiyyah Ithnā 'Ashariyyah bagi mengatakan golongan munafikin termasuk dalam pengertian sahabat adalah hadis berikut:

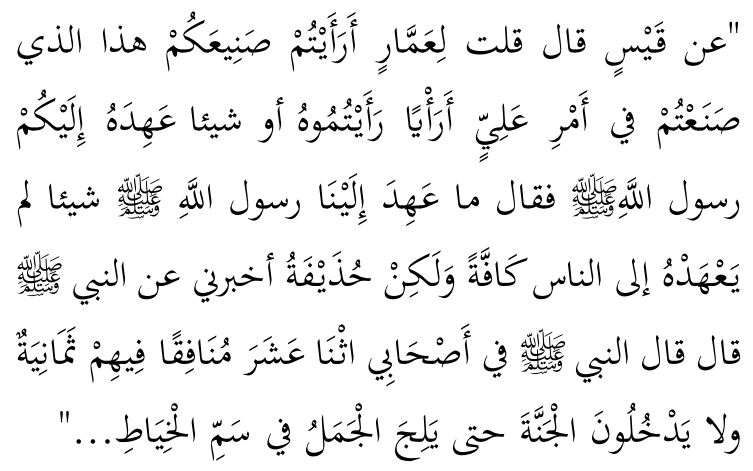

Terjemahan:

"Daripada Qays, beliau berkata: Saya pernah bertanya kepada 'Ammār: Apa pendapatmu tentang perbuatan (perang) yang kamu perbuat pada (mempertahankan) kekhalifahan 'Ali, adakah ia pendapat kamu atau sesuatu yang dipesan kepada kamu oleh Rasulullah SAW? Beliau ('Ammār) menjawab: Rasulullah SAW tidak pernah menyampaikan pesan kepada kami suatu pesan yang tidak Baginda sampaikan juga kepada orang ramai. Namun, Hudhayfah memberitahuku daripada Nabi SAW, beliau berkata bahawa Nabi SAW bersabda: Dalam

62 Hadis riwayat al-Bukhāri, Kitāb al-Tafsīir, Bāb Qawlih Ta‘ālā: "Sawā'an 'Alayhim Astaghfarta lahum am lam tastaghfir lahum, Inna Allāh la yahdi al-qawm al-fasiqīn", no. hadis: 4622. Lihat al-Jāmi “alSahịh al-Mukhtaṣar, 4: 1861; hadis riwayat Muslim, Kitāb al-Birr wa al-Șilah wa al-Adab, Bāb Nașr al-Akh Z̄āliman aw Maẓlūman, no. hadis: 2584. Lihat Sahịh Muslim, 4: 1998. 
kalangan para sahabatku, terdapat dua belas orang munafik, antara mereka lapan orang yang tidak akan masuk syurga hingga unta masuk ke lubang jarum..."63

Al-Nawawi mengatakan, maksud sahabat dalam hadis ini adalah mereka yang disandarkan sebagai sahabat kepada Rasulullah SAW, walhal mereka itu bukan sahabat dari segi syarak. Tambahan pula, terdapat riwayat lain yang menggunakan lafaz, "Dalam kalangan umatku, terdapat dua belas orang munafik..."64 Menurut al-Tūrbashti, persahabatan dengan Nabi SAW yang diperakui adalah persahabatan yang disertai dengan keimanan. Seseorang itu hanya disebut sebagai sahabat Rasulullah SAW jika persahabatannya didasari oleh iman yang benar dan terzahir padanya tanda-tanda keimanan.

Manakala mereka yang berselindung di sebalik kemunafikan, penyandaran perkataan sahabat terhadap mereka tidak harus kecuali dengan makna majāz. Ini disebabkan keserupaan mereka dengan para sahabat, berselindung di sebalik kalimah-kalimah yang benar dan pergaulan mereka di tengah-tengah para sahabat yang ramai. Oleh sebab itu, hadis tersebut menyatakan " $f \bar{i}$ așhābī" (dalam kalangan sahabatku) bukan "min aṣhābī" (daripada kalangan sahabatku). Ia seumpama mengatakan, "Iblis kān fí al-malā'ikah" bererti Iblis berada dalam kalangan malaikat, dan tidak betul jika dikatakan, "Iblis kān min al-malā'ikah" yang bererti Iblis daripada kalangan malaikat. ${ }^{65}$

${ }^{63}$ Hadis riwayat Muslim, Kitāb Șifāt al-Munāfiqīn wa Aḥkāmihim, no. hadis: 2779. Lihat Șahịh Muslim, 4: 2143.

64 Yahyā bin Sharaf al-Nawawī, Sahịh Muslim bi Sharh al-Nawawī (Beirut: Dār Ihyā̄' al-Turath 'Arabì, 1392), 17: 125.

65 'Alì bin Sulțān Muhammad al-Qārì, Mirqāt al-Mafātīh Sharh Mishkāt al-Mașābīh (Beirut: Dār al-Kutub al-'Ilmiyyah, 2001), 11: 62. 


\section{Kesimpulan}

Syiah Imāmiyyah Ithnā 'Ashariyyah pada satu sudut, dilihat bersetuju dengan takrifan sahabat menurut Ahl alSunnah wa al-Jamā'ah sebagaimana yang dikemukakan oleh Ibn Hajar dan diperakui oleh Zayn al-Dīn al-'Āmili. Namun dari sudut yang lain, para ulama mereka seperti alRiḍawī, al-Milāni dan al-Dawkhì telah memanipulasikan takrifan tersebut dengan memasukkan golongan murtad dan munafik juga sebagai sahabat, hingga menyebabkan ia terkeluar daripada takrifan sahabat menurut istilah syarak di sisi Ahl al-Sunnah wa al-Jamā'ah. Pendekatan yang sama juga diambil dalam karya Khair Izzah dan Faisal Tehrani apabila memanipulasikan definisi sahabat menurut Ahl al-Sunnah wa al-Jamā'ah dengan memberikan gambaran yang salah terhadap para sahabat. Ini menunjukkan ketidakjujuran Syiah Imāmiyyah Ithnā 'Ashariyyah dalam membincangkan definisi sahabat.

Pada hakikatnya, Syiah Imāmiyyah Ithnā 'Ashariyyah hanya mentakrifkan sahabat dari sudut bahasa. Ini terbukti dengan jelas, apabila sahabat besar seperti Abū Bakr alȘiddiq dinafikan persahabatannya yang khas dari sudut istilah sebagaimana dinyatakan dalam surah al-Tawbah ayat 40 yang bermaksud, "Ketika dia berkata kepada sahabatnya: Janganlah engkau berdukacita, sesungguhnya Allah bersama kita." Dalam tafsir yang disandarkan oleh Syiah Imāmiyyah Ithnā 'Ashariyyah kepada Imam Kesebelas (al-Hasan al-'Askari), muhaqqiq kitab tersebut iaitu Madrasah al-Imām al-Mahdi mengatakan, ayat tersebut tidak memberikan apa-apa kelebihan kepada Abū Bakr dengan gelaran "sahabat". Ini kerana, sahabat adalah perkataan umum yang boleh digunakan untuk sesiapa sahaja sama ada kawan, lawan, mukmin atau kafir. ${ }^{66}$

Al-Majlisī membawakan riwayat daripada Abū Ja'far, Muḥammad al-Bāqir (Imam Kelima) yang menafikan

66 Al-Hasan bin 'Alī, al-Tafsìr al-Mansūb ilā al-Imām al-Hasan al'Askarì (Qom: Madrasah al-Imām al-Mahdi, 1409H), 465. 
sebarang kelebihan pada Abū Bakr berdasarkan ayat tersebut. Malah persahabatan seorang mukmin dengan seorang kafir adalah perkara biasa sebagaimana yang dinyatakan dalam surah al-Kahf ayat $37 .{ }^{67}$

Kesimpulannya, istilah sahabat merupakan istilah syarak yang bersumberkan al-Qur'an dan al-Sunnah. Ia bukan istilah rekaan manusia yang disandarkan kepada syarak sebagaimana dakwaan Syiah Imāmiyyah Ithnā 'Ashariyyah. Salah faham terhadap definisi sahabat dari sudut istilah akan memberi implikasi dalam memahami konsep sahabat secara keseluruhan.

\section{Rujukan}

Al-'Āmili, Zayn al-Din. Al-Dirāyah fì 'Ilm al-Hadith. Iran: Manshūrat Maktabah al-Mufid, t.t.

Al-'Askarí, al-Ḥasan bin 'Alī. Al-Tafsìr al-Mansūb ilā al-

Imām al-Hasan al- 'Askarì. Qom: Madrasah al-Imām alMahdi, $1409 \mathrm{H}$.

Al-Anșāì, 'Umar bin 'Alì. Al-Muqni ' fì 'Ulūm al-Hadìth.

Saudi: Dār Fawwāz, 1413H.

Al-Baghdādī, Abū Bakr al-Khațīb. Al-Kifāyah fī 'Ilm alRiwāyah. Madinah: al-Maktabah al-'Ilmiyyah, t.t.

Al-Bukhārī, Muḥammad bin Ismā'il. Al-Jāmi ' al-Ṣahịh alMukhtașar. Beirut: Dār Ibn Kathīr, 1987.

Al-Dawkhī, Yahyyā bin 'Abd al-Muḥsin. 'Adālah alȘahāâh bayn al-Qadāsah wa al-Wāqi '. Iran: al-Majma' al-'Ālamì li Ahl al-Bayt, 1430H.

"Debat Sunni Syiah Masjid Perling 2013: Analisis Ringkas", Meniti Titian Sebenar, http://titiansebenar.blogspot.my/2014/02/debat-sunni-syiah-masjidperling-2013.html.

Faisal Tehrani. Perempuan Nan Bercinta. Kuala Lumpur: ITBM, 2012.

Al-Ghazālì, Abū Hāmid. Al-Mustașfā fī 'Ilm al-Uṣūl. Beirut: Dār al-Kutub al-'Ilmiyyah, 1413H.

${ }^{67}$ Al-Majlisi, Bihāar al-Anwār, 27: 322. 
Al-Hajjāj, Muslim. Șahịh Muslim. Beirut : Dār Ihyā’’ alTurāth al-'Arabi, t.t.

Al-Hakim, Muḥammad bin 'Abd Allāh. Al-Mustadrak 'alā al-Ṣahihhayn. Dār al-Kutub al-'Ilmiyyah, 1990.

Ibn Hajar al-'Asqalani, Aḥmad bin 'Ali. Al-Iṣabah fí Tamyiz al-Ṣahabah. Beirut: Dar al-Jìl, 1992.

Ibn Hibban, Muhammad. Sahịh ibn Hibbān bi Tartīb Ibn Balbān. Beirut: Mu'assasah, 1993.

Ibn Sa'd, Muhammad. Al-Țabaqāt al-Kubrā. Beirut: Dar Șādir, t.t.

Al-Juwaynī, Abū al-Ma'ālì. Al-Talkhīs fī Ușūl al-Fiqh. Beirut: Dār al-Bashā'ir al-Islāmiyyah, 1997.

Khair Izzah. Meniti Titian Kebenaran. t.t.p. : Al-Muntazar Resources, 2011.

Al-Khuḍayr, 'Abd Allāh Jarwān. Mà Qālah al-Thaqalān fī Awliyā' al-Rahmmān. Kuwait: Mabarrah al-Āl wa alAș̣āa, 2007.

Al-Majlisì, Muḥammad Bāqir. Biḥ̂ar al-Anwār al-Jāmi 'ah lidurar Akhbār al-A'immah al-Ațhār. Beirut: Dār Ihyā' al-Turāth al-'Arabì, $1403 \mathrm{H}$.

Markaz al-Risālah. Al-Ṣahābah fī al-Qur'ān wa al-Sunnah wa al-Tārīkh. Qom: Markaz al-Risālah, 1419H.

Al-Mawardi, 'Alì bin Muḥammad. A 'lām al-Nubuwwah. Beirut: Dār al-Kitāb al-'Arabì, 1987.

Al-Mìlāni, 'Alì al-Husayni. Al-Ṣaḥ̄abah. Qom: Markaz alAbhath al-'Aqā'idiyyah, $1421 \mathrm{H}$.

Murtaḍā al-'Askarì. Ma'ālim al-Madrastayn. Iraq: alMajma' al-'Ilmí al-Islāmí, 1993.

Al-Muttaqi al-Hindì. Kanzl al- 'Ummāl fï Kanz fī Sunan alAqwāl wa al-Af'āl. Beirut: Dār al-Kutub al-'Ilmiyyah, 1998.

Al-Nawawī, Yahyā bin Sharaf. Șahịh Muslim bi Sharh alNawawì. Beirut: Dār Ihyā' al-Turath 'Arabì, 1392.

Al-Qārī, 'Alì bin Sulțān Muhammad. Mirqāt al-Mafātīh Sharh Mishkāt al-Maṣābịh. Beirut: Dār al-Kutub al'Ilmiyyah, 2001. 
Al-Riḍawī, Murtaḍā. Arā' al-'Ulamā' al-Muslimīn fī alTaqiyyah wa al-Șaḥābah wa Șiyānah al-Qur'ān alKarīm. Beirut: al-Irshād li al-Ṭibā'ah wa al-Nashr, t.t. Al-Sakhāwī, Shams al-Dīn. Fath al-Mughìth Sharh Alfiyah al-Hadìth. Beirut: Dār al-Kutub al-'Ilmiyyah, 1403H. Al-Sakhāwì. Fath al-Mughìth Sharh Alfiyah al-Hadīth. Beirut: Dār al-Kutub al-'Ilmiyyah, 1403H.

Al-Sam‘ānì, Abū al-Muẓaffar. Qawātị al-Adillah fī alUșūl. Beirut: Dār al-Kutub al-'Ilmiyyah, 1997.

Seksyen Akidah. "Kertas Makluman Perkembangan Terkini Isu Syiah di Malaysia”. Bahagian Perancangan dan Penyelidikan, Jabatan Kemajuan Islam Malaysia, 2011.

Seksyen Akidah. "Kertas Makluman Perkembangan Terkini Isu Syiah di Malaysia". Bahagian Perancangan dan Penyelidikan, Jabatan Kemajuan Islam Malaysia, 2013.

Seksyen Akidah. "Laporan Mengenai Coalition Of Malaysia NGOs In The UPR Process (COMANGO)". Bahagian Perancangan dan Penyelidikan, Jabatan Kemajuan Islam Malaysia, 2013.

"Senarai Perintah Larangan", Kementerian Dalam Negeri, http://epq.kdn.gov.my/e-

pq/index.php? $\bmod =$ public\&opt $=\mathrm{pl}$.

Al-Sha'lān, 'Abd al-Raḥmān bin 'Abd Allāh. Ușūl Fiqh alImām Mālik: Adillatuh al-Naqliyyah. Riyaḍ: Jāmi'ah alImām Muḥammad bin Su'ūụ al-Islāmiyyah.

Al-Shahrazūrì, 'Uthmān bin 'Abd al-Raḥmān. Muqaddimah Ibn al-Salāh fì 'Ulüm al-Hadìth. Beirut: Dār al-Fikr al-Mu'așir, 1977.

Subhānī, Ja'far. Ușūl al-Hadith wa Aḥkāmuhu fī 'Ilm alDirāyah. Qom: Dar Jawwad, 2012.

Al-Subkī, 'Alì bin 'Abd al-Kāfī. Al-Ibhāj fī Sharh alMinhāj. Beirut: Dār al-Kutub al-'Ilmiyyah, 1404H.

Al-Tirmidhī, Muhammad bin 'Isa. Al-Jāmi' al-Ṣahịh. Beirut: Dār Ihyā̄' al-Turāth al-'Arabì, t.t. 
Mohd Aizam \& Mohd Fauzi, "Analisis Definisi Sahabat dalam Beberapa Karya Syiah Melayu," Afkār Vol. 20 Issue 1 (2018): 1-40

Al-Zayla'ī, Jamāl al-Dīn 'Abd Allāh bin Yūsuf. Takhrīj alAhāäìth wa al-Āthār al-Wāqi 'ah fī Tafsìr al-Kashshāf li al-Zamakhsharī. Riyāḍ: Dār Ibn Khuzaymah, 1414H. 
Mohd Aizam \& Mohd Fauzi, "Analisis Definisi Sahabat dalam Beberapa Karya Syiah Melayu," Afkār Vol. 20 Issue 1 (2018): 1-40 